\title{
Basic Education Students' Digital Competence in the Area of Communication: The Influence of Online Communication and the Use of Social Networks
}

\author{
Marcos Cabezas-González * (1), Sonia Casillas-Martín (1) and Ana García-Valcárcel Muñoz-Repiso (1) \\ Department of Didactics, Organization and Research Methods, University of Salamanca, 37008 Salamanca, Spain; \\ scasillasma@usal.es (S.C.-M.); anagv@usal.es (A.G.-V.M.-R.) \\ * Correspondence: mcabezasgo@usal.es
}

Citation: Cabezas-González, M.; Casillas-Martín, S.; García-Valcárcel Muñoz-Repiso, A. Basic Education Students' Digital Competence in the Area of Communication: The Influence of Online Communication and the Use of Social Networks. Sustainability 2021, 13, 4442. https: / / doi.org/ 10.3390/su13084442

Academic Editors: Pilar Colás-Bravo and Jesús Conde-Jimenez

Received: 25 March 2021

Accepted: 12 April 2021

Published: 15 April 2021

Publisher's Note: MDPI stays neutral with regard to jurisdictional claims in published maps and institutional affiliations.

Copyright: (c) 2021 by the authors. Licensee MDPI, Basel, Switzerland. This article is an open access article distributed under the terms and conditions of the Creative Commons Attribution (CC BY) license (https:/ / creativecommons.org/licenses/by/ $4.0 /)$.

\begin{abstract}
The global public health crisis unleashed by the COVID-19 pandemic has made it clear that digital competence in education is no longer an option, but a necessity. Online communication with friends using social networks is an activity in which young people very frequently and at increasingly early ages engage. This article presents the results of a study analyses digital-competence levels in the area of communication of Spanish basic-education students (aged 12-16) and establishes whether online communication with friends and the use of social media impact it. A quantitative methodology with a descriptive and cross-sectional design was used. The sample comprised 807 students, and data collection was based on a problem-solving test. Findings show that students who use online communication with their friends very often and that those who use social networks a lot have lower levels of digital competence. Education centres should reflect on this in order to implement curricular programs that may strengthen this type of competence.
\end{abstract}

Keywords: digital competence; ICT; basic education; digital communication; online communication; social networks

\section{Introduction}

Information and communication technologies (ICTs) are integrated into most areas of developed societies and are an important part of their citizens' lives [1]. Therefore, it is increasingly necessary to teach and develop the knowledge, skills, and attitudes that are required for the safe use of ICT [2].

The current global public health crisis triggered by the COVID-19 pandemic exposed important shortcomings regarding the pedagogical integration of ICTs, raising awareness of the fact that digital competence is no longer an option, but a necessity $[3,4]$. Research on this competence is currently a focus of interest in countries' education policies [5].

In Europe, digital competence is regarded as a key competence in lifelong learning and is defined as the confident, critical, and responsible use of and interaction with digital technologies for learning, at work, and for participation in society. This includes information and data-literacy communication, media literacy, digital-content creation (including programming), safety (including digital well-being and competences related to cybersecurity), intellectual-property matters, problem solving, and critical thinking [6] (p. 9).

There are different models to assess this competence. This research follows one of the benchmarks for the development of digital competences in Europe: the European Digital Competence Framework (DigComp).

Online communication with friends, understood to be an exchange of messages through different Internet platforms, is an activity in which young people very frequently engage. For this purpose, they mainly use social media, becoming familiar with them at increasingly early ages. 
This research analyses the digital-competence level in the area of communication of Spanish basic-education students (aged 12-16) and determines whether the use of social networks and online communication with friends impact it.

Over the past decade, research in the field of social networks mainly focused on studying the influence of these digital platforms on learning and communication processes, academic performance, and interpersonal relations. Very few studies analysed the link between the use of social networks and the development of digital competences in the area of communication.

This study provides scientific evidence in an area of research that is still scarcely developed. Understanding whether online communication with friends and the use of social networks defines the level of digital competence in the communication of basic-education students is important to guide institutional decisions and educational policies targeted at the development and assessment of digital competence. In Spain, basic education encompasses primary and compulsory secondary education. It comprises 10 years of academic education between the ages of 6 and 13. Its purpose is to provide mainstream education to enable the acquisition of basic cultural elements, such as spoken and written expression and comprehension, calculus, study habits, individual and cooperative work, and growing autonomy to promote the full development of students.

\section{Theoretical Foundation}

Over the last few decades, ICT has strongly impacted society [7]. From ever earlier ages, children approach technology with the same curiosity with which they contemplate the world in which they live [8]. Digital competence has become an essential part of students' lives in the context of virtual education that resulted from the global health crisis caused by the COVID-19 pandemic.

Digital competence is understood as the set of knowledge, skills, and attitudes that drive students to use ICT to work, solve problems, and participate individually and in collaboration with others in a creative, critical, and responsible way [9].

There are different standards or theoretical models of reference to assess this competence. One of the most widely used in the European continent is the European Digital Competence Framework (DigComp) [10]. In 2013, the European Commission presented the Framework for Developing and Understanding Digital Competence in Europe (DigComp 1.0) [11]. This model arranged digital-competence dimensions into five areas (information, communication, content creation, safety, and problem solving), three levels (foundation, intermediate, and advanced), and three fields (knowledge, skill, and attitude). In 2016, it was updated to the European Digital Competence Framework for Citizens (DigComp 2.0) [12], and in 2017 with version DigComp 2.1. [13].

Using the Framework for Developing and Understanding Digital Competence in Europe (DigComp 1.0) as a basis, this research assesses communication, described as follows: "communicate in digital environments, share resources through online tools, link with others and collaborate through digital tools, interact with and participate in communities and networks, cross-cultural awareness" [11]. The digital competences that it covers are: interacting through technologies, sharing information and content, engaging in online citizenship, collaborating through digital channels, netiquette, and managing digital identity. In recent years, research focused on this competence area following the European Digital Competence Framework [14-17].

Technological changes have transformed young people's way of interacting and communicating [18]. The digital revolution lead to greater social interaction among Spanish teenagers, and it is changing how they establish contact, build friendships, and communicate, affecting their routines and everyday contexts. The development of their communicative competence rests on interactions with others, connections, and friendship bonds [14], which is addressed in this study.

In their socialization process, young people make use of social networks, which are Internet-based structures that allow for people to connect with one another according to 
common interests and values to share contents in a variety of communication formats and establish interpersonal relations [19]. They provide teenagers with almost boundless possibilities to broaden their network of contacts and friends, and are shaping the dynamics of their relationships, with WhatsApp, YouTube, and Instagram being among their favourites [20,21].

The widespread use of technological devices to access social networks reveals new ways of communication [22,23]. Teenagers need to communicate, express their feelings and emotions, and project an image of themselves among their peers. They identify each other through message exchanges and gather interesting information to share with their followers [24].

Simultaneously, in the last few decades, the generalised use of social networks among younger populations drew researchers' interest in studying the educational potential of these digital tools [25-29].

Research mostly presents these applications as tools to enhance the teaching and learning process $[30,31]$. In this vein, there are studies that prove their benefits in increasing communication and interaction, fostering the collaborative building of knowledge, creativity, and the development of complex cognitive and metacognitive strategies [26,32-38]. However, there are others that draw attention to the negative effects that they may have on students, such as an increase in plagiarism, distractions that lead to decreased concentration on the learning process, and an increase in social-network addiction and dependence problems [39].

Other studies approach their influence on interpersonal relations and academic performance. In this regard, there are those that report a positive and significant impact of these digital tools on academic performance $[40,41]$. Those against this conclude that, although social networks are information and communication resources for students, their use negatively impacts their academic performance and their relationships with their classmates [42].

Research also addressed their influence in communication, providing evidence that social networking improves communication and social-interaction skills $[43,44]$, and that younger generations spontaneously develop the ability to communicate and create content in different contexts [45,46]. Moreover, certain studies reveal that these digital tools help in the acquisition of vocabulary and writing skills in foreign languages [47-49]. There are studies showing that the dialogical and iconic nature of social-networking activities is associated with the capacity to argue, debate, and provide feedback [50].

Lastly, research is scarce that identifies the influence of social networking on the level of digital competence in the area of communication of students aged 12-16, but there are studies that report that social networks clearly define the development of these young people's digital identities [14].

\section{Methodology}

The study is based on a quantitative approach with a descriptive cross-sectional design, specifically an ex post facto design [51,52].

\subsection{Goal and Hypothesis}

The general goal is to analyse the level of digital competence in the area of communication of basic-education Spanish students (aged 12-16). This is defined by the following specific objectives:

- Identify the level of digital competence in communication according to the dimensions of knowledge, skill, and attitude.

- Learn the level of digital competence in communication considering the six competences that make up this competence area (as set out in the DigComp model): interacting through technologies, sharing information and content, engaging in online citizenship, collaborating through digital channels, netiquette, and managing digital identity. 
- Verify whether online communication with friends outside school hours and the use of social networks influence the level of digital competence in communication.

The posed research hypotheses are:

Hypothesis 1. Students show an intermediate level of digital competence in the area of communication.

Hypothesis 2. Students show an intermediate level of digital competence in the six areas of competence that make up this competence area.

Hypothesis 3. Students who engage in online communication with friends outside school hours and use social networks show better levels of digital competence in the area of communication.

\subsection{Sample}

Research was carried out in the autonomous community of Castile and León (Spain). Stratified random sampling [53] was used with a $\pm 4 \%$ margin of error for a $95 \%$ confidence interval, working with a sample of 807 students aged 12-16 from 18 education centres. Gender distribution in the sample was very well balanced (Table 1).

Table 1. Sample distribution.

\begin{tabular}{ccccccccc}
\hline Total Sample & \multicolumn{2}{c}{ Year } & \multicolumn{3}{c}{ Gender } \\
\hline & 6 Primary Education & 1 Secondary Education & \multicolumn{2}{c}{ Female } & \multicolumn{3}{c}{ Male } \\
\hline $\mathrm{N}$ & $\mathrm{N}$ & $\%$ & $\mathrm{~N}$ & $\%$ & $\mathrm{~N}$ & $\%$ & $\mathrm{~N}$ & $\%$ \\
807 & 668 & 82.8 & 139 & 17.2 & 415 & 51.4 & 392 & 48.6 \\
\hline
\end{tabular}

\subsection{Variables}

Three types of variable were studied:

1. Dependent variables relating to the competence dimensions of communication: knowledge $(\mathrm{KN})$, defined as knowing, and assessed using eight multiple-choice items with four answer options each (only one of which was correct) with a 0-8 range; skill (SK), defined as know-how, and assessed using 10 multiple-choice items with four answer options each (only one of which was correct) with a 0-10 range; and attitude (AT), defined as knowing how to be assessed using six items that formed a Likert type scale of attitudes with answer scores between 1 and 5 in a 6-30 range.

2. Digital competences that comprise communication: interacting through technologies (IT), sharing information and content (SIC), engaging in online citizenship (EOC), collaborating through digital channels $(\mathrm{CDC})$, netiquette $(\mathrm{N})$, and managing digital identity (MDI). Each competence was assessed using three multiple-choice items with four answer options (only one of which was correct), with variables ranging from 0 to 3 .

3. Predictor variables defined by the frequency with which students engage in online communication with friends and make use of social networks outside school hours. Information on these variables was collected using a 5 point Likert-type scale: (1) never, (2) one/two days a week, (3) three/four days a week, (4) five/six days a week, and (5) every day.

\subsection{Instrument}

The instrument to assess digital competence in the area of communication was designed using an item bank based on a previously designed and validated model of digitalcompetence indicators in the area of communication (available at https: / gredos.usal.es/ handle/10366/139409. Accessed on 15 February 2021) and on the criteria for the development of information-gathering instruments [54]. The knowledge and skill dimensions were addressed using an objective 18 item test that presented situations where students 
were to make decisions choosing a correct answer out of four possible options. A 6 item Likert-type scale was used for attitude.

This assessment test was refined through a review by expert judges and administered to a pilot sample of 288 basic-education students. Obtained results were used to design the final test (Table 2).

Table 2. Structure of digital-competence assessment test, communication.

\begin{tabular}{cccccc}
\hline \multicolumn{2}{c}{ No. Items Per Dimension } & \multicolumn{3}{c}{ No. Items Per Level } \\
\hline Knowledge & Skill & Attitude & Foundation & Intermediate & Advanced \\
\hline 8 & 10 & 6 & 6 & 8 & 4 \\
\hline
\end{tabular}

To test the reliability of the entire test and of its different competence dimensions (knowledge, skill, and attitude), Cronbach's alpha and $\alpha_{\text {ordinal }}$ or common factor model were calculated to measure internal consistency [55] alongside Armor's theta (principalcomponent model). The latter two are considered to be more appropriate for scales that include fewer than five categories or dichotomous items, and were calculated using tetrachoric correlations and rotated factor loads following the instructions and Excel spreadsheet elaborated by Domínguez-Lara [56].

Table 3 shows the obtained data. Cronbach's alpha indices for the knowledge and skill dimensions were low $(<0.70)$, which could have been because this measure assumes the continuous nature of variables and is considered to be inadequate for scales with fewer than five categories. On the basis of the suggestions of certain authors $[57,58]$ regarding the use of this index, the dichotomous nature of the scale lead to the use of correction for attenuation (CA) to compare Cronbach's alpha and $\alpha_{\text {Ordinal }}$. The obtained values were satisfactory in all cases $(>0.70)$ and sufficient to guarantee the scales' reliability [59].

Table 3. Reliability of digital-competence assessment test, communication.

\begin{tabular}{cccccc}
\hline Dimensions & $\mathbf{N}$ & $\boldsymbol{\alpha}_{\text {ordinal }}$ & Armor's Theta & $\begin{array}{c}\text { Correction for } \\
\text { Attenuation (CA) }\end{array}$ & No. Elements \\
\hline Knowledge-Skill & 807 & 0.70 & 0.71 & $17 \%$ & 18 \\
Attitude & 788 & 0.814 & 0.80 & $11 \%$ & 6 \\
Entire area & 788 & 0.864 & 0.80 & $19 \%$ & 24 \\
\hline
\end{tabular}

Table 4 shows the difficulty index of each of the test items.

Table 4. Test structure according to item difficulty level.

\begin{tabular}{cccccc}
\hline Items & No. Items & \% Guesses & Criterion & Rating & Level \\
\hline $1,6,8,15,16,17$ & 6 & $81.2 ; 79.1 ; 66.8 ; 77.3 ;$ & $61-85$ & Easy & Foundation \\
$2,5,9,11,12,13,14,18$ & 8 & $59.4 ; 44.6 ; 53.5 ; 47.8 ; 44.7 ;$ & $41-60$ & Moderate & Intermediate \\
$3,4,7,10$ & 4 & $31.1 ; 22.7 ; 36.6 ; 35.1$ & $15-40$ & Difficult & Advanced \\
\hline
\end{tabular}

Two items were added to the digital-competence assessment test in order to collect information on practices of online communication with friends and use of social networks.

\subsection{Data Analysis}

The test's difficulty/easiness index was calculated on the basis of the number of guesses (\%) for each of the different competence dimensions (knowledge, skill, and attitude).

For data classification, the correct answer was registered as 1 , and the 3 that were incorrect as 0 . In this regard, the achieved scores in the competence dimensions and in 
each of the digital competences were obtained from the result sum of the achieved score in each item. Regarding attitude items, each answer was categorized as follows: strongly disagree (1), disagree (2), indifferent (3), agree (4), and strongly agree (5), calculating an overall score in the attitude dimension.

Descriptive and inferential analyses were performed. The Kolmogorov-Smirnov normality test was used to examine sample distribution, showing the non-normality of data $(Z=0.09 ; p<0.05)$. Consequently, analysis was performed using nonparametric tests, specifically the Kruskal-Wallis $\mathrm{H}$ test for $>2$ independent samples. The Kruskal-Wallis test is an extension of the two-group Mann-Whitney U (Wilcoxon rank) test. Thus, KruskalWallis is a more generalized form of the Mann-Whitney U test [60]. Subsequently, the data were accurately defined using the Mann-Whitney U test.

Data were analysed using SPSS v.25 and the Excel spreadsheet elaborated by Domínguez Lara [56] that is based on a tetrachoric correlation matrix for reliability analysis related to dichotomous items.

\section{Results}

Below are the main results yielded by the descriptive and inferential analyses.

\subsection{Descriptive Statistics}

Data were obtained according to the three competence dimensions defined in the test (knowledge, skill, and attitude) and the six competences into which the items were grouped: interacting through technologies (IT), sharing information and content (SIC), engaging in online citizenship (EOC), collaborating through digital channels $(\mathrm{CDC})$, netiquette $(\mathrm{N})$, and managing digital identity (MDI). The latter were created from the sum of the scores in the four items that measured each of them.

Table 5 shows the statistical measures of mean, standard deviation, skewness, and kurtosis. Since the items were dichotomous (guess 1/incorrect 0), the maximal obtained ratings in the average score were 1.

Table 5. Descriptive analysis according to competence dimensions.

\begin{tabular}{lcccccccc}
\hline Dimensions & $\mathbf{N}$ & No. Items & Min & Max & $\overline{\mathbf{x}}$ & SD & Skewness & Kurtosis \\
\hline Knowledge & 804 & 8 & 1 & 8 & 4.29 & 1.59 & -0.19 & -0.06 \\
Skill & 804 & 10 & 1 & 10 & 5.41 & 1.90 & -0.15 & -0.61 \\
Attitude & 793 & 6 & 6 & 30 & 26.02 & 4.32 & -2.39 & 9.06 \\
\hline
\end{tabular}

Regarding competence dimensions, three of them were negatively skewed. In relation to kurtosis, knowledge and skill scored below 3 and were negative in all cases; hence, distributions may be defined as platykurtic. In the attitude dimension, kurtosis was above 3 and positive, so it might be defined as leptokurtic.

The knowledge and the skill dimensions were on a midpoint on the scale, with means of 4.29 and 5.41, respectively, with maximal scores being 8 for the former and 10 for the latter. The achieved score in attitude was far above the previous, with an average of 26.02 out of 30 .

Considering digital competences, average scores oscillated between 1.28 (CDC) and $1.94(\mathrm{~N})$. Thus, students had greater knowledge and skill in netiquette and interacting through technologies, followed by managing digital identity, engaging in online citizenship, sharing information and content, and collaborating through digital channels (Table 6). 
Table 6. Descriptive analysis according to digital competences.

\begin{tabular}{ccccccc}
\hline Competences & $\mathbf{N}$ & No. Items & $\overline{\mathbf{x}}$ & SD & Skewness & Kurtosis \\
\hline $\mathrm{IT}^{1}$ & 807 & 3 & 1.72 & 0.79 & -0.32 & -0.25 \\
$\mathrm{SIC}^{2}$ & 807 & 3 & 1.46 & 0.78 & 0.96 & -0.40 \\
$\mathrm{EOC}^{3}$ & 807 & 3 & 1.57 & 0.95 & -0.07 & -0.91 \\
$\mathrm{CDC}^{4}$ & 807 & 3 & 1.28 & 0.93 & 0.22 & -0.83 \\
$\mathrm{~N}^{5}$ & 807 & 3 & 1.94 & 0.91 & -0.52 & -0.72 \\
MDI $^{6}$ & 807 & 3 & 1.69 & 2.93 & -0.21 & -0.77 \\
Total & 807 & 18 & 9.66 & 0.30 \\
\hline
\end{tabular}

${ }^{1}$ Interacting through technologies; ${ }^{2}$ sharing information and content; ${ }^{3}$ engaging in online citizenship; ${ }^{4}$ collaborating through digital channels; ${ }^{5}$ netiquette; ${ }^{6}$ managing digital identity.

The total average score achieved in the knowledge and skill test was 9.66 out of 18, which shows a foundation level of knowledge and skills in digital competence.

4.2. Inferential Statistics for Impact of Online Communication and Use of Social Networks on Level of Digital Competence in Communication

To conduct the inferential study, students were divided into 5 groups according to their online communication practices and use of social networks. The Kruskal-Wallis test for $\mathrm{k}$ independent samples was used, setting significance at $\alpha=0.05$. Differences among subsamples were analysed according to the different competence dimensions and digital competences.

\subsubsection{Online Communication with Friends}

Considering the competence dimensions (Table 7), students who scored lower in skill were those who engaged in online communication with their friends every day $(\overline{\mathrm{x}}=4.98$; $\mathrm{H}=19.66 ; p=0.03)$.

Table 7. Kruskal-Wallis H test for independent samples according to different competence dimensions.

\begin{tabular}{|c|c|c|c|c|c|c|c|}
\hline Dimension & $\begin{array}{c}\text { Frequency } \\
\text { (Days/Week) }\end{array}$ & N (\%) & $\begin{array}{l}\text { Max. Possible } \\
\text { Score }\end{array}$ & $\overline{\mathbf{x}}$ & SD & $\begin{array}{c}\text { Kruskal-Wallis } \\
\text { H }(p)\end{array}$ & Cohen's D \\
\hline \multirow{5}{*}{$\mathrm{KN}^{1}$} & Never & 227 (28.48) & \multirow{5}{*}{8} & 4.31 & 1.55 & $1.52(0.98)$ & \multirow{5}{*}{0.2} \\
\hline & $1-2$ & $229(28.73)$ & & 4.17 & 1.55 & $5.67(0.58)$ & \\
\hline & $3-4$ & 129 (16.18) & & 4.48 & 1.61 & $12.64(0.81)$ & \\
\hline & 5-6 & $43(5.39)$ & & 4.30 & 1.65 & $1.45(0.98)$ & \\
\hline & Every day & $169(21.20)$ & & 4.19 & 1.75 & $13.98(0.52)$ & \\
\hline \multirow{5}{*}{$\mathrm{SK}^{2}$} & Never & $227(28.48)$ & \multirow{5}{*}{10} & 5.41 & 1.89 & $13.87(0.18)$ & \multirow{5}{*}{0.1} \\
\hline & $1-2$ & $229(28.73)$ & & 5.56 & 1.91 & $14.97(0.13)$ & \\
\hline & $3-4$ & 129 (16.18) & & 5.65 & 1.94 & $16.66(0.08)$ & \\
\hline & 5-6 & $43(5.39)$ & & 5.26 & 2.01 & $9.96(0.44)$ & \\
\hline & Every day & $169(21.20)$ & & 4.98 & 1.91 & $19.66(0.03)$ & \\
\hline \multirow{5}{*}{$\mathrm{AT}^{3}$} & Never & $225(28.73)$ & \multirow{5}{*}{30} & 25.63 & 5.21 & $23.81(0.41)$ & \multirow{5}{*}{0.2} \\
\hline & $1-2$ & $226(28.86)$ & & 26.13 & 3.91 & $17.33(0.79)$ & \\
\hline & $3-4$ & $126(16.09)$ & & 26.58 & 3.28 & $9.83(0.99)$ & \\
\hline & 5-6 & $42(5.36)$ & & 25.74 & 4.26 & $25.68(0.32)$ & \\
\hline & Every day & $164(20.94)$ & & 26.21 & 4.18 & $14.93(0.90)$ & \\
\hline
\end{tabular}

${ }^{1}$ Knowledge; ${ }^{2}$ skill; ${ }^{3}$ attitude.

Regarding digital competences (Table 8), the highest scores in interacting through technologies were achieved by those who never use online communication with their friends $(\bar{x}=1.89 ; H=15.26 ; p=0.002)$, and the worst by those who do so every day. Statistical differences were significant in both cases. Similar results were achieved in netiquette, where students who engage in online communication with their friends daily were those who scored the lowest, with statistically significant differences $(\overline{\mathrm{x}}=1.67 ; \mathrm{H}=17.45 ; p=0.001)$. 
Table 8. Kruskal-Wallis $\mathrm{H}$ for independent samples according to digital competences.

\begin{tabular}{|c|c|c|c|c|c|c|c|}
\hline Competences & $\begin{array}{c}\text { Frequency } \\
\text { (Days/Week) }\end{array}$ & N (\%) & $\begin{array}{l}\text { Max. Possible } \\
\text { Score }\end{array}$ & $\overline{\mathbf{x}}$ & SD & $\begin{array}{c}\text { Kruskal-Wallis } \\
\text { H }(p)\end{array}$ & Cohen's D \\
\hline \multirow{5}{*}{$\mathrm{IT}^{1}$} & Never & $227(28.48)$ & \multirow{5}{*}{3} & 1.89 & 0.72 & $15.26(0.002)$ & \multirow{5}{*}{0.4} \\
\hline & $1-2$ & $229(28.73)$ & & 1.75 & 0.79 & $0.65(0.88)$ & \\
\hline & $3-4$ & 129 (16.18) & & 1.64 & 0.81 & $3.26(0.35)$ & \\
\hline & $5-6$ & $43(5.39)$ & & 1.72 & 0.83 & $0.67(0.88)$ & \\
\hline & Every day & $169(21.20)$ & & 1.52 & 0.85 & $14.65(0.002)$ & \\
\hline \multirow{5}{*}{$\mathrm{SIC}^{2}$} & Never & $227(28.48)$ & \multirow{5}{*}{3} & 1.44 & 0.74 & $3.86(0.35)$ & \multirow{5}{*}{0.2} \\
\hline & $1-2$ & 229 (28.73) & & 1.50 & 0.80 & $1.37(0.71)$ & \\
\hline & $3-4$ & 129 (16.18) & & 1.53 & 0.77 & $5.24(0.15)$ & \\
\hline & 5-6 & $43(5.39)$ & & 1.51 & 0.96 & $6.54(0.08)$ & \\
\hline & Every day & $169(21.20)$ & & 1.40 & 0.77 & $4.08(0.25)$ & \\
\hline \multirow{5}{*}{$\mathrm{EOC}^{3}$} & Never & $227(28.48)$ & \multirow{5}{*}{3} & 1.50 & 0.99 & $4.76(0.19)$ & \multirow{5}{*}{0.2} \\
\hline & $1-2$ & $229(28.73)$ & & 1.54 & 0.93 & $1.38(0.71)$ & \\
\hline & $3-4$ & 129 (16.18) & & 1.68 & 0.96 & $5.25(0.15)$ & \\
\hline & 5-6 & $43(5.39)$ & & 1.49 & 0.86 & $3.07(0.38)$ & \\
\hline & Every day & $169(21.20)$ & & 1.64 & 0.93 & $1.71(0.63)$ & \\
\hline \multirow{5}{*}{$\mathrm{CDC}^{4}$} & Never & $227(28.48)$ & \multirow{5}{*}{3} & 1.28 & 0.92 & $0.58(0.90)$ & \multirow{5}{*}{0.2} \\
\hline & $1-2$ & $229(28.73)$ & & 1.27 & 0.91 & $0.80(0.85)$ & \\
\hline & $3-4$ & 129 (16.18) & & 1.39 & 0.97 & $4.49(0.21)$ & \\
\hline & 5-6 & $43(5.39)$ & & 1.05 & 0.95 & $4.13(0.25)$ & \\
\hline & Every day & $169(21.20)$ & & 1.26 & 0.94 & $0.70(0.87)$ & \\
\hline \multirow{5}{*}{$\mathrm{N}^{5}$} & Never & $227(28.48)$ & \multirow{5}{*}{3} & 2.02 & 0.92 & $2.39(0.50)$ & \multirow{5}{*}{0.1} \\
\hline & $1-2$ & 229 (28.73) & & 1.98 & 0.91 & $2.03(0.56)$ & \\
\hline & $3-4$ & $129(16.18)$ & & 2.05 & 0.97 & $3.26(0.35)$ & \\
\hline & 5-6 & $43(5.39)$ & & 2.05 & 0.97 & 2.07 (0.55) & \\
\hline & Every day & $169(21.20)$ & & 1.67 & 1.02 & $17.45(0.001)$ & \\
\hline \multirow{5}{*}{$\mathrm{MDI}^{6}$} & Never & $227(28.48)$ & & 1.60 & 0.91 & $3.13(0.37)$ & \multirow{5}{*}{0.2} \\
\hline & $1-2$ & 229 (28.73) & & 1.69 & 0.89 & $4.01(0.26)$ & \\
\hline & $3-4$ & 129 (16.18) & 3 & 1.84 & 0.90 & $5.75(0.12)$ & \\
\hline & 5-6 & $43(5.39)$ & & 1.74 & 0.87 & $0.82(0.84)$ & \\
\hline & Every day & $169(21.20)$ & & 1.67 & 0.95 & $2.21(0.53)$ & \\
\hline
\end{tabular}

${ }^{1}$ Interacting through technologies; ${ }^{2}$ sharing information and content; ${ }^{3}$ engaging in online citizenship; ${ }^{4}$ collaborating through digital channels; ${ }^{5}$ netiquette; ${ }^{6}$ managing digital identity.

In light of these results, groups were more accurately defined, distinguishing between those who used online communication with their friends every day and those who did not. The Mann-Whitney U test to compare two independent samples was used, setting the significance level at 0.05 for significant differences, and at 0.01 for highly significant differences (Table 9).

Table 9. Nonparametric analysis Mann-Whitney U test-online communication with friends.

\begin{tabular}{cccccc}
\hline Variables & Mann-Whitney U Test & Wilcoxon W & Z & $p$ & r Effect Size \\
\hline KN $^{1}$ & $51,139.00$ & $65,504.00$ & -1.05 & $0.002^{* *}$ & 0.2 \\
SK $^{2}$ & $45,506.00$ & $59,871.00$ & -3.15 & $0.002^{* *}$ & 0.1 \\
AT $^{3}$ & $50,130.50$ & $248,265.50$ & -0.56 & 0.58 & 0.2 \\
IT $^{4}$ & $45,505.50$ & $59,870.50$ & -3.39 & $0.001^{* *}$ & 0.4 \\
SIC $^{5}$ & $50,252.00$ & $64,617.00$ & -1.46 & 0.14 & 0.2 \\
EOC $^{6}$ & $51,066.50$ & $254,907.50$ & -1.10 & 0.27 & 0.2 \\
CDC $^{7}$ & $53,346.50$ & $67,711.50$ & -0.22 & 0.83 & 0.2 \\
N $^{9}$ & $44,024.00$ & $58,389.00$ & -3.86 & $0.00^{* *}$ & 0.1 \\
MDI $^{9}$ & $53,616.00$ & $67,981.00$ & -0.11 & 0.91 & 0.2 \\
\hline
\end{tabular}

${ }^{1}$ Knowledge ${ }^{2}$ skill. ${ }^{3}$ attitude; ${ }^{4}$ interacting through technologies; ${ }^{5}$ sharing information and content; ${ }^{6}$ engaging in online citizenship; ${ }^{7}$ collaborating through digital channels; ${ }^{8}$ netiquette; ${ }^{9}$ managing digital identity; ${ }^{* *}$ significant at 0.01 . 
Considering competence dimensions, significant differences were found in knowledge $(\mathrm{z}=-1.05 ; p=0.002)$, where those who communicate with their friends online every day scored lower $(\overline{\mathrm{x}}=4.19 ; \mathrm{sx}=1.66)$ than those who $\operatorname{do} \operatorname{not}(\overline{\mathrm{x}}=4.27 ; \mathrm{sx}=1.61)$. There were also significant differences in skill $(\mathrm{z}=-3.15 ; p=0,002)$ among those who communicate daily $(\overline{\mathrm{x}}=4.98 ; \mathrm{sx}=1.91)$ and those who do not $(\overline{\mathrm{x}}=5.39 ; \mathrm{sx}=1.92)$, the latter having achieved better test results. These differences show that students who do not engage in online communication with friends every day obtained better results in both knowledge and skill.

Regarding digital competences, the only significant differences were found in interacting through technologies $(\mathrm{z}=-3.39 ; p=0.001)$ between those who use online communication with friends every day $(\bar{x}=1.52 ; \mathrm{sx}=0.85)$ and those who do not $(\overline{\mathrm{x}}=1.72 ; \mathrm{sx}=0.79)$, and in netiquette $(\mathrm{z}=-3.86 ; p=0.00)$ between the most $(\overline{\mathrm{x}}=1.67 ; \mathrm{sx}=1.02)$ and the least $(\bar{x}=1.93 ; \mathrm{sx}=0.96)$ connected. These are the only competences where students who do not use online communication with their friends every day were found to have achieved significantly better results.

\subsubsection{Use of Social Networks}

Considering competence dimensions, those who use social networks seven days a week showed lower scores in skill $(\bar{x}=4.82 ; \mathrm{H}=19.08 ; p=0.03)$ (Table 10).

Table 10. Kruskal-Wallis $\mathrm{H}$ test for independent samples according to competence dimensions.

\begin{tabular}{|c|c|c|c|c|c|c|c|}
\hline Dimension & $\begin{array}{c}\text { Frequency } \\
\text { (Days/Week) }\end{array}$ & N (\%) & $\begin{array}{l}\text { Max. Possible } \\
\text { Score }\end{array}$ & $\overline{\mathbf{x}}$ & SD & $\begin{array}{c}\text { Kruskal-Wallis } \\
\text { H }(p)\end{array}$ & Cohen's D \\
\hline \multirow{5}{*}{$\mathrm{KN}^{1}$} & Never & $370(45.85)$ & \multirow{5}{*}{8} & 4.41 & 1.50 & $13.33(0.10)$ & \multirow{5}{*}{0.1} \\
\hline & $1-2$ & $171(21.19)$ & & 4.20 & 1.66 & $13.26(0.10)$ & \\
\hline & $3-4$ & $70(8.67)$ & & 4.36 & 1.66 & $6.11(0.63)$ & \\
\hline & 5-6 & $47(5.82)$ & & 4.57 & 1.77 & $8.10(0.42)$ & \\
\hline & Every day & $138(17.10)$ & & 3.90 & 1.72 & $14.09(0.08)$ & \\
\hline \multirow{5}{*}{$\mathrm{SK}^{2}$} & Never & $370(45.85)$ & \multirow{5}{*}{10} & 5.54 & 1.93 & $15.45(0.12)$ & \multirow{5}{*}{0.1} \\
\hline & $1-2$ & $171(21.19)$ & & 5.44 & 1.93 & $9.93(0.45)$ & \\
\hline & $3-4$ & $70(8.67)$ & & 5.53 & 1.87 & $9.93(0.45)$ & \\
\hline & 5-6 & $47(5.82)$ & & 5.66 & 1.96 & $12.08(0.28)$ & \\
\hline & Every day & 138 (17.10) & & 4.82 & 1.87 & $19.08(0.03)$ * & \\
\hline \multirow{5}{*}{$\mathrm{AT}^{3}$} & Never & $368(46.40)$ & \multirow{5}{*}{30} & 26.03 & 4.78 & $29.07(0.18)$ & \multirow{5}{*}{0.2} \\
\hline & $1-2$ & $168(21.18)$ & & 26.10 & 4.04 & $12.37(0.96)$ & \\
\hline & $3-4$ & $68(8.57)$ & & 26.81 & 3.06 & $10.32(0.99)$ & \\
\hline & 5-6 & $46(5.80)$ & & 25.78 & 2.87 & $20.88(0.59)$ & \\
\hline & Every day & $132(16.64)$ & & 25.78 & 3.73 & $24.59(0.37)$ & \\
\hline
\end{tabular}

${ }^{1}$ Knowledge ${ }^{2}$ skill; ${ }^{3}$ attitude; ${ }^{*}$ significant at 0.05 .

Regarding digital competences (Table 11), in interacting through technologies, students who never use social networks achieved the highest scores $(\overline{\mathrm{x}}=1.82 ; \mathrm{H}=13.47$; $p=0.004)$ while those who use them every day obtained the lowest $(\overline{\mathrm{x}}=1.49 ; \mathrm{H}=17.63$; $p=0.001)$. Both samples revealed significant differences. Likewise, in sharing information and content, those who most often use social networks achieved worse results $(\overline{\mathrm{x}}=1.32$; $\mathrm{H}=8.28 ; p=0.04)$. In collaborating through digital channels, the best scores were achieved by those who never use them $(\overline{\mathrm{x}}=1.33 ; \mathrm{H}=7.61 ; p=0.05)$. This is also the case with netiquette, where there are statistically significant differences showing that the worst competence level corresponded to those who use social networks every day $(\overline{\mathrm{x}}=1.53 ; \mathrm{H}=31.47$; $p=0.00$ ). In managing digital identity, there were statistically significant differences in both those who never use them $(\overline{\mathrm{x}}=1.63 ; \mathrm{H}=10.35 ; p=0.02)$ and those who use them every day $(\overline{\mathrm{x}}=1.67 ; \mathrm{H}=11.06 ; p=0.01)$, with both groups being on the lowest competence level. 
Table 11. Kruskal-Wallis H test for independent samples according to digital competences.

\begin{tabular}{|c|c|c|c|c|c|c|c|}
\hline Competences & $\begin{array}{c}\text { Frequency } \\
\text { (Days/Week) }\end{array}$ & N (\%) & $\begin{array}{l}\text { Max. Possible } \\
\text { Score }\end{array}$ & $\overline{\mathbf{x}}$ & SD & $\begin{array}{c}\text { Kruskal-Wallis } \\
\text { H (p) }\end{array}$ & Cohen's D \\
\hline \multirow{5}{*}{$\mathrm{IT}^{1}$} & Never & $370(45.85)$ & \multirow{5}{*}{3} & 1.82 & 0.75 & $13.47(0.004)$ * & \multirow{5}{*}{0.4} \\
\hline & $1-2$ & $171(8.80)$ & & 1.72 & 0.85 & $2.52(0.47)$ & \\
\hline & $3-4$ & $70(8.67)$ & & 1.66 & 0.68 & $5.43(0.14)$ & \\
\hline & 5-6 & $47(5.82)$ & & 1.74 & 0.74 & $0.83(0.84)$ & \\
\hline & Every day & 138 (17.10) & & 1.49 & 0.87 & $17.63(0.001)$ * & \\
\hline \multirow{5}{*}{$\mathrm{SIC}^{2}$} & Never & $370(45.85)$ & \multirow{5}{*}{3} & 1.52 & 0.77 & $3.46(0.33)$ & \multirow{5}{*}{0.1} \\
\hline & $1-2$ & $171(8.80)$ & & 1.49 & 0.76 & $1.66(0.64)$ & \\
\hline & $3-4$ & $70(8.67)$ & & 1.46 & 0.74 & $0.94(0.82)$ & \\
\hline & 5-6 & $47(5.82)$ & & 1.51 & 0.83 & $1.30(0.73)$ & \\
\hline & Every day & $138(17.10)$ & & 1.32 & 0.83 & $8.28(0.04)$ * & \\
\hline \multirow{5}{*}{$\mathrm{EOC}^{3}$} & Never & $370(45.85)$ & \multirow{5}{*}{3} & 1.61 & 0.97 & $3.11(0.37)$ & \multirow{5}{*}{0.2} \\
\hline & $1-2$ & $171(8.80)$ & & 1.53 & 0.91 & $2.16(0.54)$ & \\
\hline & $3-4$ & $70(8.67)$ & & 1.56 & 0.97 & $0.09(0.99)$ & \\
\hline & 5-6 & $47(5.82)$ & & 1.79 & 0.91 & $3.85(2.28)$ & \\
\hline & Every day & $138(17.10)$ & & 1.47 & 0.95 & $2.16(0.54)$ & \\
\hline \multirow{5}{*}{$\mathrm{CDC}^{4}$} & Never & $370(45.85)$ & \multirow{5}{*}{3} & 1.33 & 0.96 & $7.61(0.05)$ * & \multirow{5}{*}{0.2} \\
\hline & $1-2$ & $171(8.80)$ & & 1.18 & 0.93 & $6.19(0.10)$ & \\
\hline & $3-4$ & $70(8.67)$ & & 1.34 & 0.95 & $0.63(0.89)$ & \\
\hline & 5-6 & $47(5.82)$ & & 1.32 & 0.98 & $1.58(0.66)$ & \\
\hline & Every day & 138 (17.10) & & 1.24 & 0.82 & $7.17(0.07)$ & \\
\hline \multirow{5}{*}{$\mathrm{N}^{5}$} & Never & $370(45.85)$ & \multirow{5}{*}{3} & 2.04 & 0.92 & $7.28(0.06)$ & \multirow{5}{*}{0.4} \\
\hline & $1-2$ & $171(8.80)$ & & 1.96 & 0.93 & $1.08(0.78)$ & \\
\hline & $3-4$ & $70(8.67)$ & & 2.14 & 0.97 & $6.35(0.09)$ & \\
\hline & 5-6 & $47(5.82)$ & & 2.04 & 0.88 & $1.45(0.69)$ & \\
\hline & Every day & 138 (17.10) & & 1.53 & 1.01 & $31.47(0.00)$ * & \\
\hline \multirow{5}{*}{$\mathrm{MDI}^{6}$} & Never & $370(45.85)$ & & 1.63 & 0.87 & $10.35(0.02)$ * & \multirow{5}{*}{0.2} \\
\hline & $1-2$ & $171(8.80)$ & & 1.77 & 0.92 & $2.71(0.44)$ & \\
\hline & $3-4$ & $70(8.67)$ & 3 & 1.73 & 0.85 & $1.42(0.70)$ & \\
\hline & 5-6 & 47 (5.82) & & 1.83 & 0.96 & $3.29(0.35)$ & \\
\hline & Every day & 138 (17.10) & & 1.67 & 1.03 & $11.06(0.01)$ * & \\
\hline
\end{tabular}

${ }^{1}$ Interacting through technologies; ${ }^{2}$ sharing information and content; ${ }^{3}$ engaging in online citizenship; ${ }^{4}$ collaborating through digital channels; ${ }^{5}$ netiquette; ${ }^{6}$ managing digital identity; ${ }^{*}$ significant at 0.05 .

Using these results as a basis, the groups were further defined to check for significant differences between those who use social networks seven days a week and those who do not. The Mann-Whitney $U$ test was used to compare two independent samples, setting the significance level at 0.05 for significant differences and at 0.01 for highly significant differences (Table 12).

Table 12. Nonparametric analysis, Mann-Whitney U test-use of social networks.

\begin{tabular}{cccccc}
\hline Variables & Mann-Whitney U Test & Wilcoxon W & Z & $p$ & r Effect Size \\
\hline KN $^{1}$ & $38,985.00$ & $48,576.00$ & -2.93 & $0.003^{* *}$ & 0.1 \\
SK $^{2}$ & $37,226.50$ & $46,817.50$ & -3.63 & $0.000^{* *}$ & 0.1 \\
AT $^{3}$ & $39,900.00$ & $48,678.00$ & -1.56 & 0.12 & 0.2 \\
IT $^{4}$ & $38,051.50$ & $47,642.50$ & -3.54 & $0.000^{* *}$ & 0.4 \\
SIC $^{5}$ & $40,627.50$ & $50,218.50$ & -2.39 & $0.02^{* *}$ & 0.1 \\
EOC $^{6}$ & $43,108.00$ & $52,699.00$ & -1.28 & 0.20 & 0.1 \\
CDC $^{7}$ & $45,494.50$ & $55,085.50$ & -0.28 & 0.78 & 0.2 \\
N $^{9}$ & $33,412.50$ & $43,003.50$ & -5.37 & $0.000^{* *}$ & 0.4 \\
MDI & $45,982.50$ & $270,097.50$ & -0.07 & 0.94 & 0.2 \\
\hline
\end{tabular}

${ }^{1}$ Knowledge; ${ }^{2}$ skill; ${ }^{3}$ attitude; ${ }^{4}$ interacting through technologies; ${ }^{5}$ sharing information and content; ${ }^{6}$ engaging in online citizenship;

7 collaborating through digital channels; ${ }^{8}$ netiquette; ${ }^{9}$ managing digital identity; ${ }^{* *}$ significant at 0.01 . 
Focusing on competence dimensions, the following significant differences could be observed: in knowledge $(z=-2.93 ; p=0.003)$, between students who use them every day of the week $(\bar{x}=3.90 ; \mathrm{sx}=1.72)$ and those who do not $(\overline{\mathrm{x}}=4.35 ; \mathrm{sx}=1.58)$; in skill $(\mathrm{z}=-3.63$; $p=0.000)$, between those who use them every day $(\bar{x}=4.82 ; \mathrm{sx}=1.87)$ and those who do $\operatorname{not}(\bar{x}=5.50 ; s x=1.92)$. Hence, findings reveal that the best results in the knowledge and skill tests are achieved by those who do not use social networks every day.

Regarding the analysis of digital competences in this area of communication, significant differences were found in interacting through technologies $(z=-3.54 ; p=0.000)$, between those who use social networks every day $(\overline{\mathrm{x}}=1.49 ; \mathrm{sx}=0.87)$ and those who do not $(\bar{x}=1.76 ; s x=0.77)$; in sharing information and content $(z=-2.39 ; p=0.02)$, between those who make greater use of them $(\overline{\mathrm{x}}=1.32 ; \mathrm{sx}=0.83)$ and those who use them less frequently $(\bar{x}=1.49 ; \mathrm{sx}=0.77) ;$ and in netiquette $(\mathrm{z}=-5.37 ; p=0.000)$, between those who connect every day $(\bar{x}=1.53$; sx $=1.01)$ and those who do so to a lesser extent $(\bar{x}=2.03 ; s x=0.93)$. In all cases, the students who do not use them seven days a week obtained significantly better results.

\section{Discussion}

In recent years, different studies analysed the digital competence of teachers and students taking the European Digital Competence Framework as a basis (DigComp), and almost always focusing on more than one or all of the competence areas [61-67]. Research was also conducted on the influence of social and personal variables such as gender, age, digital-device ownership, and activities performed using technology on the level of digital competence [68-72]. However, there are no studies on the impact of online communication and the use of social networks on the level of digital competence in the area of communication of students aged 12-16.

Students' level of digital competence in this area qualifies as a pass (or foundation level) in knowledge and skill. These results are consistent with the findings of other studies that also assessed this competence area in Spanish basic-education students [14,16], but disagree with studies that claim that Peruvian secondary-education students achieved adequate results in the addressed digital competences (interacting through technologies, sharing information and content, collaborating through digital channels, netiquette, and managing digital identity) [17]. In the attitude dimension, assessments proved to be very positive, which is in line with the results of other studies [73-75]. These findings lead to the rejection of the first and second suggested hypotheses.

Regarding the influence of the frequency of use of online communication with friends on students' competence level, significant statistical differences were found in the dimensions of knowledge and skill. Students who do not communicate so often achieved better results.

Considering the digital competences encompassed by communication, only two revealed significant differences: interacting through technologies and netiquette. Students who do not engage in online communication with friends every day achieved better results.

Regarding the influence of the frequency of social network use variable on competence level, statistically significant differences appeared in the dimensions of knowledge and skill in favour of those who do not use them every day.

In relation to digital competences, significant differences were found in three: interacting through technologies, sharing information and content, and netiquette. In all, students who use social networks less showed greater digital competence.

Variables corresponding to the frequency of use of online communication with friends and the use of social networks lead to the rejection of the third posed hypothesis.

In the online communication and social-networking area of study, several published studies provide evidence that both improve communication skills [43,44]. Moreover, they contribute towards vocabulary acquisition and training in writing $[47,48]$, and improve argumentation and discussion abilities [50]. Nevertheless, where the e-communication area 
of study is concerned, and as proven in this research, engaging in online communication with friends and using social networks does not improve digital skills.

Online communication and social networking may be helpful for teenagers to identify through message exchanges with friends and by sharing content of interest with their followers [23,24], but not to improve their level of digital competence in the area of communication as defined by the DigComp model. These competences could require a more specific and structured type of learning that young people do not acquire in an autonomous manner.

There are also studies that conclude that, although social networks are information and communication resources for students, their use may result in dependency [76-78] and negatively impact their academic performance $[42,79,80]$. Furthermore, the findings of this study showed a negative influence on the development of digital communication.

Similarly, certain studies note that social networks clearly define the development of the digital identity of students aged 12-16 [14]. However, according to this research, these young people do not have enough knowledge and skills to manage their digital identity.

Lastly, although the results of this study are the product of thorough quantitative analysis of the collected data, it would be very interesting to supplement it with qualitative data that may complete and further develop the reported findings.

\section{Conclusions}

This research analysed the level of digital competence in the area of communication of Spanish basic-education students (aged 12-16), examining whether online communication with friends and the use of social networks impact it.

The aim of the study was to contribute scientific evidence to a research area that remains underdeveloped. Understanding whether online communication and the use of social networks defines young people's level of digital competence in the area of communication is key to guide institutional decisions and educational policies aimed at the development and assessment of digital competence.

Although the attitude towards digital communication of students in the 12-16 age range is strongly positive, their level of knowledge and skills is only basic. This is a matter of concern if we bear in mind that the use of digital devices to communicate online through social networks is one of the activities in which these young people most frequently engage. It is also worrying that this datum surfaces in the context of the current healthcare crisis resulting from COVID-19, where digital competence is no longer an option but a necessity.

Against what collective thinking could expect, using online communication with friends and social networks very frequently does not improve these students' digital competence at neither the conceptual nor the procedural level. It could also be detrimental to the development of specific digital competences such as interacting through technologies, sharing information and content, collaborating through digital channels, or managing digital identity.

These results are by no means surprising. They validate our hypothesis that Spanish students aged 12-16 lack adequate digital competence in the area of communication. Indeed, these young people are skilled at using different technological devices to meet needs that are mainly related to interpersonal interaction, being connected, and friendships because of their need to communicate, share their feelings and emotions, and project their personal image among their peers. However, their concerns are not focused on knowing how to adequately interact with digital devices, collaborate using digital channels, using technology to improve the environment, or learning how they should manage their digital identity.

Competence in digital communication involves far more than the use of technological devices to communicate with peers. It means learning to communicate in digital environments, sharing resources, establishing ties with others, collaborating through the use of digital tools, and participating and interacting in communities and social networks with intercultural awareness and respect. 
In these times, when digital competence is a basic requirement, it is necessary to develop it as part of school curricula by including digital-literacy programmes either as independent modules or as a cross-curricular subject.

Author Contributions: M.C.-G. edited the paper and wrote Section 1, Section 2, Section 5, Section 6. S.C.-M. structured the paper and wrote Section 3, Section 4, and Section 6. A.G.-V.M.-R. supervised the process and wrote Sections 3 and 4 . All authors equally contributed to write and review this paper. All authors have read and agreed to the published version of the manuscript.

Funding: Article produced in the framework of the research and development project "Evaluación de las competencias digitales de los estudiantes de Educación Obligatoria y estudio de la incidencia de variables socio-familiares" ("Assessment of the digital competences of Basic Education students and study of the impact of social and family variables"), developed by the Research-Innovation in Educational Technology Group of the University of Salamanca (GITE-USAL) and funded by the Ministry of Economy and Competitiveness as part of the State Program for the Promotion of Excellence Scientific and Technical Research of the Spanish Government (EVADISO, EDU2015-67975C3-3-P, MINECO/FEDER).

Institutional Review Board Statement: The study was conducted according to the guidelines of the Declaration of Helsinki and approved by the Ethical Committee of the University of Salamanca.

Informed Consent Statement: Informed consent was obtained from all subjects involved in the study.

Data Availability Statement: The data presented in this study are available on request from the corresponding author. The data are not publicly available due to privacy.

Conflicts of Interest: The authors declare no conflict of interest.

\section{References}

1. Valverde-Crespo, D.; De Pro-Bueno, A.; González-Sánchez, J. Secondary students' digital competence when searching and selecting scientific information. Enseñanza De Las Ciencias 2020, 38, 81-103. [CrossRef]

2. Galindo-Domínguez, H.; Bezanilla, M.J. Promoting time management and self-efficacy through digital competence in university students: A mediational model. Contemp. Educ. Technol. 2021, 13, 1-14. [CrossRef]

3. Sánchez-Cruzado, C.; Santiago Campión, R.; Sánchez-Compaña, M.T. Teacher Digital Literacy: The Indisputable Challenge. Sustainability 2021, 13, 1858. [CrossRef]

4. Díaz-Arce, D.; Loyola-Illescas, E. Digital comptecence in the contexto f COVID 19: A view from education. Revista Innova Educación 2021, 3, 120-150. [CrossRef]

5. Cabero-Almenara, J.; Palacios-Rodríguez, A. Metareflexion on digital teaching comptecence: Competence frameworks'analysis. Rev. Panorâmica 2020, 32, 32-48. Available online: http:/ / revistas.cua.ufmt.br/revista/index.php/revistapanoramica/article/ view/1239/19192420 (accessed on 22 January 2021).

6. European Union (2018, 22 de Mayo). Recomendación C 189 Relativa a las Competencias Clave Para el Aprendizaje Permanente. Diario Oficial de la Unión Europea, 4 de junio de 2018. Available online: https:/ / eur-lex.europa.eu/legal-content/ES/TXT/ PDF/?uri=CELEX:32018H0604(01)\&from=SV (accessed on 25 October 2020).

7. Ramírez-Rueda, M.C.; Cózar-Gutiérrez, R.; Roblizo Colmenero, M.J.; González-Calero, J.A. Towards a coordinated vision of ICT in education: A comparative analysis of Preschool and Primary Education teachers' and parents' perceptions. Teach. Teach. Educ. 2021, 100, 103300. [CrossRef]

8. González García, N. Use of Information and Communication Technology by the elementary students of El Zethe community, Aculco, State of Mexico. Acta Educ. 2021, 60, 1-8.

9. Hatlevik, O.; Guðmundsdóttir, G.; Loi, M. Digital diversity among upper secondary students: A multilevel analysis of the relationship between cultural capital, self-efficacy, strategic use of information and digital competence. Comput. Educ. 2015, 81, 345-353. [CrossRef]

10. Ivanović, D.; Simović, V. DigComp-MethodologicaL frame for measuring digital competencies. Trendovi U Poslovanju 2020, 8 , 83-92. [CrossRef]

11. Ferrari, A. DigComp: A Framework for Developing and Understanding Digital Competence in Europe; Publications Office of the European Union: Luxembourg, 2013. [CrossRef]

12. Vuorikari, R.; Punie, Y.; Carretero, S.; Van den Brande, L. DigComp 2.0: The Digital Competence Framework for Citizens. Update Phase 1: The Conceptual Reference Model; Publication Office of the European Union: Luxembourg, 2016. [CrossRef]

13. Carretero, S.; Vuorikari, R.; Punie, Y. DigComp 2.1. The Digital Competence Framework for Citizens; Publications Office of the European Union: Luxembourg, 2017. [CrossRef]

14. Rodríguez-Groba, A.; Martínez-Piñeiro, E.; González-Villa, A. Lights and shadows in the e-communication of Galician pre-teens. Rev. Iberoam. Tecnol. Aprendiz. 2021, 16, 122-131. [CrossRef] 
15. Martínez-Piñeiro, E.; Gewerc, A.; Rodríguez-Groba, A. Digital competence of primary school students in Galicia. The socio-family influence. RED Revista Educación Distancia 2019, 19, 1-25. [CrossRef]

16. Paredes-Labra, J.; Freitas-Cortina, A.; Sánchez-Antolín, P. From the initiation to tolerated use of technologies. The digital competence of Madrid students before high school. RED Revista Educación Distancia 2019, 19, 1-22. [CrossRef]

17. Orosco, J.R.; Gómez Galindo, W.; Pomasunco, R.; Salgado, E.; Álvarez Casabona, R.C. Digital Skills among High School Students in a Central Peruvian Province. Revista Educación 2021, 45, 1-17. [CrossRef]

18. Moreno-Morilla, C.; Guzmán-Simon, F.; García-Jiménez, E. Digital and information literacy inside and outside Spanish primary education schools. Learn. Cult. Soc. Interact. 2021, 28, 100455. [CrossRef]

19. Hernández-Pérez, F. The risks of information and communication technologies. Rev. Conamed 2019, 24, 184-199.

20. García-Ruiz, R.; Pérez Escoda, A. Empower citizenship through education in digital media. Hamut 'ay 2019, 6, 7-23. [CrossRef]

21. Chávez Márquez, L.; Gutiérrez Diez, M.C. Social networks as learning facilitators for exact sciences in higher education. Apertura 2015, 7, 1-12.

22. Barón Pulido, M.; Duque Soto, A.; Mendoza Lozano, F.; Quintero Peña, W. Social networks and digital relations, a communication that exceeds the face to face. Rev. Int. Pedagog. Innovación Educ. 2021, 1, 123-148.

23. Ballesta Pagán, F.J.; Lozano Martínez, J.; Cerezo Máiquez, M.C.; Castillo Reche, I.S. Participation in social networks by secondary school students. Educación XX1 2021, 24, 141-162. [CrossRef]

24. Ibrahim, N.F.; Wang, X.; Bourne, H. Exploring the effect of user engagement in online Brand communities: Evidence from twitter. Comput. Hum. Behav. 2017, 72, 321-338. [CrossRef]

25. Fernández-Díaz, E.; Rodríguez-Hoyos, C.; Haya Salmón, I. Analysis of international and national research on the use of social networks sites in educational contexts. Profr. Rev. Currículum Form. Profr. 2017, 21, 313-332.

26. Zulkanain, N.; Miskon, S.; Abdullah, N.; Ali, N.; Bahari, M. Social Network Sites (SNS) Utilization in Learning LandscapeSystematic Literature Review. In Recent Trends in Data Science and Soft Computing. IRICT 2018. Advances in Intelligent Systems and Computing; Saeed, F., Gazem, N., Mohammed, F., Busalim, A., Eds.; Springer: Cham, Germany, 2019; Volume 843, pp. 963-972. [CrossRef]

27. Valero, A.; Vendrell, M.; Camas, L. The educational use of Social Networks Sites: A comparative analysis between the Spanish and English production. Digit. Educ. Rev. 2020, 37, 304-322. [CrossRef]

28. González, M.; Muñoz, P.; Dans, I. Factors which motivate the use of social networks by students. Psicothema 2017, 29, 204-210. [CrossRef]

29. Alhussain, T.; Mugahed Al-Rahmi, W.; Shahizan Othman, M. Students' Perceptions of Social Networks Platforms use in Higher Education: A Qualitative Research. Int. J. Adv. Trends Comput. Sci. Eng. 2020, 9, 2589-2603. [CrossRef]

30. Camas Garrido, L.; Valero Moya, A.; Vendrell Morancho, M. The teacher-student relationship in the use of social network sites for educational purposes: A systematic review. J. New Approaches Educ. Res. 2021, 10, 137-156. [CrossRef]

31. García, A.C.; Gil-Mediavilla, M.; Álvarez, I.; Casares, M.Á. The influence of social networks within educational and social fields: A comparative study between two generations of online students. Sustainability 2020, 12, 9941. [CrossRef]

32. Rodríguez-Hoyos, C.; Haya, I.; Fernández-Díaz, E. Research on SNS and education: The state of the art and its challenges. Australas. J. Educ. Technol. 2015, 31, 100-111. [CrossRef]

33. Bouton, E.; Bar Tal, S.; Asterhan, C.S.C. Students, social network technology and learning in higher education: Visions of collaborative knowledge construction vs. the reality of knowledge sharing. Internet High. Educ. 2021, 49, 100787. [CrossRef]

34. García-Martín, S.; Cantón-Mayo, I. Use of technologies and academic performance in adolescent students. Comunicar 2019, 27, 73-81. [CrossRef]

35. Pedro, L.; Barbosa, C.; Santos, C. A critical review of mobile learning integration in formal educational contexts. Int. J. Educ. Technol. High. Educ. 2018, 15, 1-10. [CrossRef]

36. Muñoz-Carril, P.C.; Dans-Álvarez-de-Sotomayor, I.; González-Sanmamed, M. Social Networks and Their Uses in The Field of Secondary Education. In Social Network Analytics. Computational Research Methods and Techniques; Dey, N., Borah, S., Babo, R., Ashour, A., Eds.; Academic Press.: Cambridge, MA, USA; Elsevier Inc.: London, UK, 2019; pp. 203-226. [CrossRef]

37. Wang, W.; Lam, E.T.H.; Lung, M.M.-W.; Chiu, D.K.W. Supporting higher education with social networks: Trust and privacy vs perceived effectiveness. Online Inf. Rev. 2020, 45, 207-219. [CrossRef]

38. Craig, K.; Humburg, M.; Danish, J.A.; Szostalo, M.; Hmelo-Silver, C.E.; McCraine, A. Increasing students' social engagement during COVID-19 with Net.Create: Collaborative social network analysis to map historical pandemics during a pandemic. Inf. Learn. Sci. 2020, 121, 533-547. [CrossRef]

39. Suranto, J.; Syah, M.F.; Kristiana, D.N.; Puspita, R.W. Analysis of social networks utilization in student learning patterns. Int. J. Innov. Creat. Chang. 2020, 11, 87-99.

40. Lahiry, S.; Choudhury, S.; Chatterjee, S.; Hazra, A. Impact of social media on academic performance and interpersonal relation: A cross-sectional study among students at a tertiary medical center in East India. J. Edu. Health Promot. 2019, 8, 73. [CrossRef]

41. Thanh Tung, L.; My Ha, T. Impact of Social Network Usage on Academic Performance of the Vietnamese Students. Univers. J. Educ. Res. 2020, 8, 4179-4186. [CrossRef]

42. Habes, M.; Alghizzawi, M.; Khalaf, R.; Salloum, S.A.; Ghani, M.A. The Relationship between Social Media and Academic Performance: Facebook Perspective. Int. J. Inf. Technol. Lang. Stud. 2018, 2, 12-18. 
43. Ndege, W.; Mutavi, T.; Kokonya, D.; Nekesa, V.; Musungu, B.; Obondo, A.; Wangari, M. Social networks and students' perfomance in secondary schools: Lessons form an Open Learning Centre, Kenya. J. Educ. Pract. 2015, 6, 171-178.

44. Gurjar, N. Leveraging Social Networks for Authentic Learning in Distance Learning Teacher Education. Tech Trends 2020, 64, 666-667. [CrossRef]

45. Scroeder, R. Towards a theory of digital media. Inf. Commun. Soc. 2018, 21, 323-339. [CrossRef]

46. Pérez Escoda, A. Usage of smartphone and social media in primary school students. Prism. Soc. 2018, 20 , 77-91.

47. Motlagh, H.S.; Khafaie, H.; Arastoo, A.A.; Cheraghi, M.; Khafaie, M.A. Application of social network in traditional sciences education on the vocabulary acquisition of secondary English learner students. Educ. Inf. Technol. 2020, 25, 3071-3085. [CrossRef]

48. Alam, I.; Shah, A.H. Investigating the Impact of Social Networks on English Writing Anxiety of the Common First-Year Students. Asian Efl J. 2020, 27, 193-237.

49. Ning, R. Chinese graduate students in Catalonia: Learning Catalan within the social networks in a bilingual society. J. Multiling. Multicult. Dev. 2020, 1-16. [CrossRef]

50. Jiménez-Cortés, R. Ubiquitous learning of the young women in the social networks sites and their awareness of learning. Prism. Soc. 2015, 15, 180-221.

51. Cohen, L.; Manion, L.; López, F.A. Educational Research Methods; La Muralla: Madrid, Spain, 1990.

52. Pérez Juste, R.; Galán González, A.; Quintanal Diaz, J. Research Methods and Designs in Education; Universidad Nacional de Educación a Distancia: Madrid, Spain, 2012.

53. Casal, J.; Mateu, E. Types of sampling. Rev. Epidem. Med. Prev. 2003, 1, 3-7.

54. McMillan, J.H.; Schumacher, S. Educational Research, 5th ed.; Pearson Educación: Madrid, Spain, 2005.

55. Welch, S.; Comer, J. Quantitative Methods for Public Administration: Techniques and Applications; Brooks/Cole: Pacific Grove, CA, USA, 1998.

56. Domínguez-Lara, S. Reliability and ordinal alpha. Actas Urológicas Españolas 2018, 42, 140-141. [CrossRef]

57. Zumbo, B.D.; Gadermann, A.M.; Zeisser, C. Ordinal versions of coefficients alpha and theta for Likert rating scales. J. Mod. Appl. Stat. Methods 2007, 6, 20-29. [CrossRef]

58. Oliden, P.E.; Zumbo, B.D. Reliability coefficients for ordered categorical response scales. Psicothema 2008, 20, 896-901.

59. Morales, P.; Urosa, B.; Blanco, A. Constructing Likert-Type Attitude Scales: A Practical Guide; Cuadernos de Estadística: Madrid, Spain, 2003.

60. Kruskal, W.H.; Wallis, W.A. Use of ranks in one-criterion variance analysis. J. Am. Stat. Assoc. 1952, 47, 583-621. [CrossRef]

61. Rayna, T.; Striukova, L. Fostering skills for the 21st century: The role of Fab labs and makerspaces. Technol. Forecast. Soc. Chang. 2021, 164, 120391. [CrossRef]

62. Jiménez-Hernández, D.; González-Calatayud, V.; Torres-Soto, A.; Martínez Mayoral, A.; Morales, J. Digital Competence of Future Secondary School Teachers: Differences According to Gender, Age, and Branch of Knowledge. Sustainability 2020, $12,9473$. [CrossRef]

63. Jin, K.-Y.; Reichert, F.; Cagasan, L.P.; de la Torre, J.; Law, N. Measuring digital literacy across three age cohorts: Exploring test dimensionality and performance differences. Comput. Educ. 2020, 157, 103968. [CrossRef]

64. Reisoğlu, İ; Çebi, A. How can the digital competences of pre-service teachers be developed? Examining a case study through the lens of DigComp and DigCompEdu. Comput. Educ. 2020, 156, 103940. [CrossRef]

65. Wild, S.; Schulze Heuling, L. Re-evaluation of the D21-digital-index assessment instrument for measuring higher-level digital competences. Stud. Educ. Eval. 2021, 68, 100981. [CrossRef]

66. Guggemos, J.; Seufert, S. Teaching with and teaching about technology-Evidence for professional development of in-service teachers. Comput. Hum. Behav. 2021, 115, 106613. [CrossRef]

67. García-Valcárcel Muñoz-Repiso, A.; Casillas-Martín, S.; Basilotta Gómez-Pablos, V.M. Validation of an indicator model (INCODIES) for assessing student digital competence in basic education. J. New Approaches Educ. Res. 2020, 9, 110-125. [CrossRef]

68. Cabezas-González, M.; Casillas-Martín, S.; García-Peñalvo, F.J. The Digital Competence of Pre-Service Educators: The Influence of Personal Variables. Sustainability 2021, 13, 2318. [CrossRef]

69. Palomares-Ruiz, A.; Cebrián, A.; López-Parra, E.; García-Toledano, E. ICT Integration into Science Education and Its Relationship to the Digital Gender Gap. Sustainability 2020, 12, 5286. [CrossRef]

70. Lucas, M.; Bem-Haja, P.; Siddiq, F.; Moreira, A.; Redecker, C. The relation between in-service teachers'digital competence and personal and contextual factors: What matters most? Comput. Educ. 2021, 160, 104052. [CrossRef]

71. Almerich, G.; Suárez-Rodríguez, J.; Díaz-García, I.; Orellana, N. Structure of 21st century competences in students in the sphere of education. Influential personal factors. Educación XX1 2020, 23, 45-74. [CrossRef]

72. Juhaňák, L.; Zounek, J.; Záleská, K.; Bárta, O.; Vlčková, K. The relationship between the age at first computer use and students'perceived comptetence and autonomy in ICT usage: A mediation analysis. Comput. Educ. 2019, 141, 103614. [CrossRef]

73. Casillas-Martín, S.; Cabezas-González, M.; García-Peñalvo, F.J. Digital competence of early childhood education teachers: Attitude, knowledge and use of ICT. Eur. J. Teach. Educ. 2020, 43, 210-223. [CrossRef]

74. Casillas-Martín, S.; Cabezas-González, M.; Ibarra-Saiz, M.S.; Rodríguez-Gómez, G. University professors in the knowledge society: Management and attitude towards ict. Bordón 2020, 72, 45-63. [CrossRef]

75. Basilotta, V.; García-Valcárcel, A.; Casillas-Martín, S.; Cabezas-González, M. Evaluation of information literacy skills in students and a study of several influential variables. Revista Complutense Educación 2020, 31, 517-528. [CrossRef] 
76. Ayar, D.; Özalp, G.; Özdemir, E.; Bektaş, M. The Effect of Problematic Internet Use, Social Appearance Anxiety, and Social Media Use on Nursing Students' Nomophobia Levels. Cin Comput. Inform. Nurs. 2018, 36, 589-595. [CrossRef] [PubMed]

77. Muñiz-Rivas, M.; Callejas-Jerónimo, J.E.; Povedano-Díaz, A. Virtual social network dependence and school climate in dating violence in adolescence. Int. J. Sociol. Educ. 2020, 9, 213-233. [CrossRef]

78. Maldonado Berea, G.A.; García González, J.; Sampedro Requena, B.E. The effect of ICT and social networks on university students Rev. Iberoam. Educ. Distancia 2019, 22, 153-176. [CrossRef]

79. Helou, A.; Rahim, N. Students' perceptions on social networking sites influence on academic performance. Int. J. Soc. Netw. Virtual Communities 2012, 1, 7-15.

80. Martelo, R.J.; Jimenez-Pitre, I.; Martelo, P.M. Impact of social networks to academic performance of students of the University of La Guajira (Colombia). Espacios 2017, 38, 24. 